The Project of the other: Developing inclusive learning communities in schools

Hugh Busher, School of Education, University of Leicester

Acc by Oxford Review 31 (2) 2005 


\title{
The Project of the other: Developing inclusive learning communities in schools
}

\author{
Author's note \\ Dr. Hugh Busher, a senior lecturer in the School of Education, University of Leicester, has research \\ interests in leadership and organisational culture, change processes and micro-politics, teacher \\ professional development and the creation of inclusive education. He is a council member for the \\ British Educational Research Association
}

Estimated word length: 7640 ex-references, and end papers

Address for Correspondence:

Dr Hugh Busher, School of Education, University of Leicester, 21 University Road, Leicester, LE1 7RF, UK. Tel: +44 (0)116 252 3688; fax: +44 (0)116 2523653

email: hugh.busher@leicester.ac.uk 


\title{
The Project of the other: Developing inclusive learning communities in schools
}

\begin{abstract}
This paper considers the possible nature and membership of learning communities in schools and what evidence there may be of middle leaders trying to develop and sustain learning communities with their colleagues, even though these communities encompass asymmetrical power relationships between members. Although it is argued that students and support staff are part of these learning communities, not apart from them, the limited evidence from this study does not support this. How power is used and distributed to construct collaborative cultures, and the part played by middle leaders, is central to the development of a learning community. The promotion of dialogue and consultation amongst members helps them to generate a sense of community which, in turn, enables them to tackle effectively the tasks and dilemmas facing them. Empirical evidence from a small scale study in England, UK, indicates the ways in which some middle leaders have tried to build learning communities, and their colleagues views on their efforts, while negotiating the value-laden tensions and dilemmas inherent in all middle management posts in educational organisations.
\end{abstract}




\section{Introduction}

This paper arises out of a small scale research project that explored how members of subject and pastoral departments in some secondary schools worked, and the part that middle leadership, a role that can be defined in a variety of ways depending on the nature of the department (Busher and Harris, 1999), played in that. The term middle leadership is used through out this paper in part to indicate the commonality between the work of departmental leaders, whether they are responsible for and to subject departmental colleagues and students or pastoral departmental colleagues and students, and in part to avoid long winded phrases.

One conceptual framework for understanding the dynamic interactions that took place in the subject and pastoral departments is the notion of professional learning communities. Clark (199x: 28) perceived communities as social systems which have a purpose, the members of which fulfil a diversity of roles within a recognisable and sustainable collectivity. Senge (1990) perceived learning communities as sites where people expand their capacities to work in new and creative ways through working together, a not unreasonable description of what takes place in schools.

This raises a question about who has membership of a school or professional learning community. In many departments in secondary schools not only teachers have membership of them, but support staff, too. Indeed earlier research by Busher and Saran (1995) suggests that support staff play an important part in the construction of a school as an organisation or community - Sergiovanni (1994) teases out the important differences between these two perspectives - and are an integral element of many departmental teams (Busher and Blease, 2000). Further, an organisational perspective on schools and other institutions draws a clear line between things and people (Giddens, 1979). As Greenfield (1993: 103) points out, 'organisations are accomplished by people and people are responsible for what goes on in them'. If this framework is pursued then students or pupils also have to be included within the notion of a learning community in schools, since they are people within the corporation of a school, not objects that are the constructions or outcomes of it or, indeed, its customers as the arguments for applying total quality management to schools maintain (West-Burnham, 1992).

Thus to talk of learning communities in schools, one has to encompass all the potential members of it. Linstead (1993) suggests that ethnographic interest in multiple voices in organisations is part epistemological and part ethical (p.53). These include the support staff and their middle leaders, teachers, students and their carers or parents - although the extent to which parents can be said to be part of a school organisation is debatable (Gray, 1991) - as well as school governors, and teachers in various promoted posts such as departmental leaders, assistant headteachers, and headteachers or principles. Students do the work of creating knowledge through their learning and the teachers, support staff and parents or carers lead, manage and support them in this activity. Within a school students have considerable impact on the construction of its culture (Marsh, 1997; Busher and Barker, 2003), whether or not they are commonly included in discourses about professional interactions in schools and whether or not they are conventionally marginalised from discourses about school organisational process and construction by being labelled customers or learners, or dehumanised as school outcomes in league tables of school performance. Linstead (1993: 59) describes this as students helping to write the texts of schools, perceiving the construction of organisations as an intertextual process that takes place between the authors and actors of it and in it. It raises questions about how students' acute awareness of the processes of schooling and the many insights they have of them (Rudduck et al, 1996; Rudduck and Flutter, 2000) can be heard and acknowledged by staff at all levels in order to contribute positively to the development of a school. It also raises questions about how staff, especially senior staff, are constrained by the 
cultures in which they find themselves working. Bottery (2003) also rejects the notion of learning communities being exclusive on grounds of race, religion, or finance. In these circumstances to label learning communities as 'professional' seems at best confusing and at worst an indication of some covert exclusivity - restricted to the professional members of a school, presumably the teachers, although some other staff might claim membership, too. It also risks ignoring the needs all members of a school have for support in developing and reflecting on relevant work-related skills, knowledge and processes of interpersonal relationships.

This raises three questions then: What is the nature of a learning community? What is the nature and distribution of power within a learning community? How are the values and culture that underpin the sense and notion of community and the ways in which power and influence are used affect the ways in which teachers work with each other and with others.

\section{So, what is a learning community?}

Learning communities can be as large as a whole school or as small as a classroom, or a subject department or pastoral area in a secondary school in England and Wales. It is where a group of people are trying to learn together, although that does not mean that all have equal power to direct or shape that learning process. Senge (1990) perceived learning communities as sites where people expand their capacities to work in new and creative ways through working together. Smylie (1994) thought they have collaborative cultures, allowing teachers to work interdependently to promote student learning. Louis et al (1996) point out the importance of members sharing values and of reflective dialogue to improve practice. It implies a culture of trust between members (Blase and Blase, 1994) that allows them to take risks, perhaps through sharing ideas and receiving constructive feedback from colleagues. Such a culture allows teachers, support staff and students to tackle complex problems as effectively as possible (Hargreaves, 1994) by building on existing expertise, pooling resources and providing each other with moral support. It revolves around social values that emphasise an awareness of others and is a key part in developing the distinctive collaborative cultures of learning communities (Wallace et al, 1997).

The characteristics of effective schools and departments (Sammons et al., 1997) and of the cultures of improving schools claimed by Stoll and Fink (1996) point to synergies between successful learning communities and high achievement, not to a conflict between the two. At the core of both lies the nurturing of others to promote learning which has been put forward as one of the main purposes of schooling (Cooper et al, 2000), especially in Primary schools (Nias, 1999). Central government legislation in England and Wales recognises the importance of this by emphasising the social and emotional development of students alongside academic achievement (Dearing, 1993). However many aspects of current central government education policy in England and Wales contradict this, emphasising a narrow academic attainment as the only measure of students' success through, for example, league tables, OFSTED reports, and literacy and numeracy hours.

The development of school learning communities is in part shaped by their leaders and managers at all levels and in part by the members of them. Their collaborative cultures develop through people working together. Although fostered by leaders at various levels in an organisation through modelling particular values in their interpersonal relationships and engaging in rigorous reflection on the values they espouse and enact (Schon, 1987), these also develop through the ways in which different members of these communities choose to interact with each other to reflect their personal social values. However only managers by definition have authority that arises from their formal posts in the organisational hierarchy of a school or college (Gronn, 2003), although other people 
can also gain access to power (Busher, 2001). They use this to implement various policies and practices through working with other people in diverse ways to project a vision of how the school or an aspect of it should develop. Having awareness of and sympathy with the social, emotional and work-related needs of staff colleagues and students helps leaders and teachers to implement policy and practices more successfully (Blase and Blase, 1994) in a western anglo-phone culture. To some extent this awareness may depend on who they are as people, their personhood (Aubrey et al 2000), and the values they project through that, in other words on the identities they have constructed for themselves in their past and present interactions with other people (Giddens, 1991).

Part of that awareness of others concerns the differentiated access to power and authority that members of learning communities have, and of the impact of social and policy contexts inside and outside school on their work, and how that shapes their relationships with each other. Smyth et al (2000) point out that teachers in developing their work-related identities 'have to contend with the power relationships that operate in schools and educational systems' (p.149). Howard and Gill (2000) point out that even young children develop understandings of power and powerlessness from their experiences at home and school. Bottery (2003) points out that vigorous learning communities inevitably invite their members to develop critical perspectives of the impact that external social, organisational, political and economic contexts have on the ways in which they work and would like to work. Not only middle leaders or school level managers, such as school principals, have access to a variety of sources of power and authority (Busher, 2001), but teachers do too (Bourdieu and Passeron, 1977). Students and parents also have power that they may exercise legitimately, if only through resistance to policies (van der Westhuisen, 1996) when their views and interests are overlooked. Hoyle (1981) points out how teachers can exert power over head teachers, and students and parents can use the same strategies over teachers.

How access to these sources of power is used affects the relationships between middle leaders and their colleagues and shape the decisions that are taken and the ways in which they can be implemented. Middle leaders using power with or through people (Blase and Anderson, 1995) tend to enable colleagues and students to enhance their positive work-related identities and engage collaboratively with their work. If power is used manipulatively rather than facilitatively then leaders are likely to promote corporatism (Tannenbaum and Schmidt, 1973), however soft the means they may be using, and cynicism amongst staff about consultative processes (Busher and Saran, 1992). It suggests that leaders who wish to promote learning communities have to act as servant leaders (Murphy, 199x) or possibly as social architects to distribute power amongst community members and facilitate individual and collective development. Teachers working with students face the same situation. Gunter et al (2001) point out that teachers are leaders in the classroom who guide and manage the learning processes.

Using power to improve working practices has a moral dimension as well as an instrumental one, as Ribbins (1999) points out, since all choice making involves permitting some events to happen at the expense of others and this choice is rooted in the implicit and explicit values of the choice makers. Schools and classrooms are sites for debating and developing particular values as well as conduits through which they can be transmitted. Fullan (2003: 3) suggests that moral purpose is at the heart of the role of public schools in democratic societies, and sees moral imperatives operating at every level within a school because the intention of schooling is to benefit students in terms of desirable identifiable goals and particular cultures of social and production relationships in which are embedded certain values, whether or not these are clearly articulated. Hodgkinson (1999: 8) argues that leaders cannot ignore these values and there impact on social relationships and working practices. Hargreaves (1994) suggests that to construct successful teaching and learning these values are those of teachers working collaboratively with each other and with other people who are 
not teachers. Hopkins (2001) argues that this depends on teachers developing authentic relationships and fostering social cohesion. Such arguments apply equally to how all staff in a school might work together and with students and their carers, even though the latter relationships encompass strongly asymmetrical power differences. The extensive literature on effective classroom leadership by teachers, for example, Wragg et al (2000) and Cooper and McIntyre (1996) points to exactly the same quality of relationships being needed in classrooms, at least in England and Wales.

\section{Research study}

While acknowledging this broad construction of the notion of learning communities in schools, the research on which this paper is based focused on the development of learning communities amongst a subset of this broader learning community, that of the teaching staff in some pastoral and subject departments in some secondary school in the midlands of England, UK, in 2001/02. In particular it focuses on the work of some subject and pastoral leaders, following the work of Measor and Sikes (1992). Siskin (1994) points out that subject areas are critical sites for developing teachers' practices. As the study included subject and pastoral leaders, the term middle leader is preferred except where indicating a person's particular status. The study used an interpretative approach to explore how people constructed and construed meanings in their social situations, following Ribbins (1997) view that is only by listening to people's voices that one really finds out what it is like to be and to work in an institution like a school.

The study focused on six middle leaders (three men and three women) in their secondary school contexts who were observed in action and interviewed about their practice. They were selected opportunistically from among schools and departments that regularly have PGCE students on placement with them. They came from a variety of different sized departments, following the views of Busher and Harris (1999), including two pastoral departments (Sixth Forms); a history department; a humanities faculty (including history, geography and RE departments); and an English department. I also interviewed their departmental colleagues (10 in all: four men and six women) and senior staff (four men and one woman) about their work. Their colleagues were found by snowball sampling to minimise ethical problems of talking with people about others without permission, and because it was an expeditious means of finding such participants. The triangulation of middle leaders' views of their work with that of staff colleagues was intended to strengthen the authenticity of the study by addressing doubts about the trustworthiness of single authored texts (Thomas, 1995). It allowed me to check their espoused theories of practice against their enacted theories (Schon, 1987). However in this paper it is mainly the middle leaders' voices that are heard. All the interviews were semi-structured, as were the observations of middle leaders working with colleagues and with students and teaching in classrooms. In addition relevant documents about each school and department were collected.

The views that emerged from middle leaders and their staff colleagues were remarkably homogeneous, but this may be explained by the way in which the sample was constructed. The paper does not seek to establish or suggest any predictive generalisations from the study's findings, merely to report what was found in these six departments.

\section{Evidence of the project of the other: building learning communities}


How middle leaders and their colleagues interacted to operate departments and construct departmental cultures emerged under four sections: one focusing on middle leaders' instrumental, technical and political activities to implement the curriculum; a second focusing on middle leaders' interpersonal relationships with colleagues; a third focusing on middle leaders as curriculum leaders facilitating students' learning; and a fourth focusing on middle leaders' reflections on practice. Whatever the focus actions were underpinned by values that were often clearly articulated and helped shape departments' cultures. The tensions and contradictions between values in some actions were often acknowledged.

\section{Section One: Instrumental, technical and political activities in policy contexts}

Functionalist perspectives on school management would probably describe the following perspectives under the term boundary management, but that term seems to under estimate the proactivity of middle leaders in this study in this aspect of their work, and obscures the ways they interacted with different contexts, particular the external contexts of government policy and pressures from communities in the schools catchment area, as compare with the internal contexts of senior school management policy.

\section{a) Middle leaders' perspectives on working with external and internal policy contexts}

Middle leaders recognised that their work and professional relationships were bounded and influenced by national government education policy, be it the National curriculum:

I would quite happily [only] talk about rain forests coasts and rivers ... but the National curriculum also says I have to do settlement, population, development (female subject leader)

Or new imposed management processes:

Quite a lot of people are not very happy about doing performance management but recognise that ... it is a hoop that they have to jump through (female subject leader)

Their work with colleagues and students was also affected by the local communities in which their schools were located:

The main problem is [students saying] 'I am not part of this religion. My dad says I don't have to do this. So I am not going to learn it' ... I don't know what sort of programmes they watch at home (male subject leader)

Middle leaders showed an acute awareness of the distribution of power and the hierarchy of authority in schools. They acknowledged the legitimacy of the senior management team (SMT) to manage the school strategically:

Basically the school will layout what areas they want covered on the school improvement plan ... I will have six sections to fill in with the headings laid down by SMT and then we will have a humanities section (female subject leader)

But acknowledge the power wielded by SMT through acting as gatekeepers to resources: 
I have always been very well supported by SMT in the budget. Provided you could justify what you wanted, they would support that if possible ... But there have been occasions when I have come into loggerheads with SMT (female subject leader)

Middle leaders regarded themselves as intermediaries between the SMT and their departmental colleagues, both representing their and their colleagues' views to the SMT, as well as acting as agents of the SMT. As the latter they tried to persuade colleagues to acquiesce to SMT policy, albeit while trying to help colleagues gain ownership of the processes of its implementation:

But I act as the lynch pin and also as the person who feeds to the department the aims of the school ... and how we can bring those aims down through into the department and in to a classroom level (female subject leader)

Middle leaders projected power to implement value-based collaborative management of departments. They claimed they had the delegated authority from SMT to manage their departments operationally.

I think that as a subject leader and middle manager ... I have very clear expectations of what I want from the faculty and I am very much prepared... to stand up for what I believe in ... Sometimes what I want is reasonable but may be the department [staff] don't agree. The bottom line is I am the head of faculty and this is how we are going to do it, like it or not, and if you have a problem with it you will have to take it higher (female subject leader)

However they also believed they had to have the consent of their colleagues if they, as middle leaders, were to implement decisions about the curriculum successfully. This took the form of listening to colleagues' perspectives on how policy might be implemented, especially when that had been imposed by senior management - as emerged in a department meeting that was observed - and in acknowledging colleagues' preferences as far as possible:

The underlying principle ... will be to give staff as much as possible what they want ... certain staff ... specifically enjoy teaching the older students (male subject leader)

Another major source of authority, the middle leaders claimed, when trying to manage their departments was the ability:

to be a proven classroom teacher ... If you can show that to colleagues through the response of the students that you teach (male subject leader)

Observational data showed that the middle leaders in this study were effective teachers.

To manage their departments successfully, the middle leaders thought it important to encompass various elements. One of these was to have a strategic vision for their departments that they could implement with their colleagues:

It is up to me as subject leader to know where the department is going, to have the vision for where the department ... and to think about the steps to achieve that, but then to work with [colleagues] ... to move the department on (female subject leader) 
A second was to provide physical and intellectual resources to facilitate the work of their colleagues:

It is no good asking [teachers] to do a group exercise if the resources are not there for them ... trying to share ideas, mainly through schemes of work, putting teaching methods down, for example. But also just being there when people come along and say 'have you got any ideas? What about this? (female subject leader)

A third was to co-ordinate their departments effectively through centralised administrative systems which middle leaders monitored:

We have central resources and common schemes of work, common assessment, common [student] records that we put on to excel that can be monitored to see how different classes are doing and that staff are meeting deadlines (female subject leader)

A subset of this was managing curriculum materials effectively. Stock cupboards in several departments held neatly labelled boxes of resources and teachers were expected to return resources they had borrowed at the end of every lesson to them.

A fourth was to take decisions about resources in a transparent and principled way. The educational values they proclaimed and appeared to enact tended to be more egalitarian than the meritocratic ones enshrined in national policy and focused inclusively on raising students' achievements:

We would want to spend the money fairly and equally across all the students ... Obviously with the National Curriculum ... we have to make sure that all the students have got the right book allocation and all the other resource allocations (male subject leader)

A fifth was to engage their colleagues in taking decisions about managing the departments by actively consulting with them through formal channels of timetabled meetings and informal approaches:

But the actual real running takes place constantly through out the day, breaks, lunchtimes and during lessons ... it is done informally through conversations in here [humanities office] ... wander into each other's lessons [to] pass on information in that way (male teacher)

Middle leaders expressed concern when some members of a department were not easily accessible for consultation:

One of the guys is on a different corridor and that is a problem because I don't see him very much and his head of subject doesn't see him very much ... I think that has had an effect on him and how he feels as part of the department (female subject leader)

However one subject leader claimed not every teacher wanted to be involved in consultation:

They don't really take much part in decision-making processes. I ask for consultation, but they often don't want to be involved because it involves effort or giving up time. So therefore I make the decisions (female subject leader)

A sixth was to create social cohesion in their departments, as is discussed later. 
In large measure the colleagues of the middle leaders shared their views of how they managed the departments. Teachers welcomed the ways in which their middle leaders defended and represented them and the department to other staff, especially the SMT. Bradley and Roaf (1995) described this as a form of advocacy.

I had some trouble with the trip to Warwick castle with [SMT] after I had been ... and looked round and done the worksheets ... [SMT] suddenly said we couldn't go. [Head of faculty] was straight up there: why? This is what [I] has done, taken one day out of her half term to go there. We have booked the coach, sent out letters [to parents], so why are you now saying we can't go. [And the trip is now going ahead] (female teacher)

Teachers welcomed middle leaders managing their departments effectively, even if this also constrained their work by creating a corporate framework into which their teaching was required to fit:

He is a very good strategic planner and manager of things ... He ensures that targets are clear for students and monitors how far students are achieving their targets ... checks with other [people] about the strategies we are using to improve [students' work] ... So everybody knows exactly when things need to be done, what is involved, and how to do it (female teacher)

When asked to clarify what aspects of effective management they liked, teachers signalled they liked being involved in decision-making, but preferred informal processes of consultation to the more formal.

We have a formal briefing every Thursday morning and then we have a faculty meeting once every four or five weeks ... after school for an hour. But the actual real running takes place constantly through out the day (male teacher)

They commented adversely when they were not involved.

Teachers welcomed the provision of resources to support their work, whether this took the form of middle leaders providing support through reference to their position-derived authority:

Having a problem with one of my students ... and then [subject leader] ... put him on faculty report and then monitored this student - sent a letter home, spoke to this student after lesson (female teacher)

or knowledge and information about organising the curriculum and coping with the school system,

[Head of faculty] has this very good knowledge of how things work and who to approach ... the right people to go and talk to and in what order ... She has given me INSET on writing schemes of work (male teacher) 
or physical and intellectual resources for the curriculum.

Section Two: Interpersonal relationships between middle leaders and their colleagues

a)

Middle leaders views

Middle leaders held remarkably homogeneous views about what constituted effective working relationships the teachers, but acknowledged that they had to work with different individual teachers in different ways within this conceptual framework. Several thought that working effectively with colleagues was the hardest part of their job. Although most of the middle leaders were very complementary about their colleagues, especially in departments where they had worked together for a considerable number of years:

very lucky to have a very good set of English teachers whom I trust implicitly to do the job ... It still means I have to have an overview of everything to make sure the job is being done. (male subject leader)

they recognised that some of their colleagues were not so engaged. One subject leader of a small department described her colleagues as 'tired teachers' who did not want to get involved in curriculum development:

Their job is to teach ... deliver the curriculum ...structured by me in my head of department role. Otherwise they have to answer to me or someone above me ... With a different department I would like to think things could be much more forward thinking (female subject leader)

One aspect of the process of working successfully with colleagues they thought involved generating social cohesion with their colleagues, at least in the context of the work place, despite the inevitable professional disagreements.

socially as a team, although we are so diverse, we chat in the staff room. At the end of term we have a faculty meal either in school or we go out. Some of the faculty go to the pub on a Friday, not every week. Other members go at different times (female subject leader)

Another aspect involved how they perceived their relationships with their colleagues and projected their authority and power with them. They perceived themselves as the first among equals, the principle of cabinet government in Britain, not as part of a separate management cadre:

within your subject area it has to be a team ... that works together. I ... [take] a lead in terms of developing schemes of work, of monitoring standards, and discussing ideas within the team. The team contribute to that ... The subject leader gives suggestions as to what should happen... so the team can share that and have ownership of that (male subject leader)

It led one middle leader to assert that he did not 'think personally there is much of a difference' between being a teacher and a subject leader and considered 'the priority is being a classroom teacher'.

This person-oriented approach to management acknowledged the professional and personal needs and interests of teachers who worked in the middle leaders' departments: 
I don't see any reason in asking or making staff teach groups or year groups they don't want to ... If the staff are happy in teaching the groups ... that will benefit the students (male subject leader)

and to value being part of a forward looking learning community based on clearly articulated values

We have not thought that we have been in the job so long that we have nothing to learn. I think sometimes we are still uncertain about our capabilities ... we do not want to let the students down. So we have this shared ethos ... do primarily the best for the students (male subject leader)

\section{b) Other teachers' views of middle leaders' social and interpersonal relationships}

Teacher colleagues of the middle leaders thought the personhood of the middle leader very important:

He is a very easy person to work with ... You [work] because you respect him ... He is a very approachable man ... [ a good] sense of humour ... He will help out if things are going wrong ... He is friendly. And you know that he is putting in as much effort as you are (female teacher)

And recognised it helped to construct particular departmental cultures:

There is this atmosphere around the place that is very nice to be in ... [head of faculty] is ... very good at team building ... at delivering criticism with a smile ... it is just a sum of her personality traits ... It is very different to how it was ... under the previous head of faculty, who was verging on going into senior management and was slightly older, so gave us a slightly different atmosphere (male teacher)

They appreciated being valued for the work they did as well as for who they were:

He will always look for ways of making your job easier ... tries to give us that sense of our importance in the whole system, and that we are valued ... People need to feel valued for what they do (female teacher)

This social cohesion helped departments to work together, even when members of it had workrelated disagreements:

Relationship between the faculty are generally very good. We obviously have our spats now and again but overall... [We] are all fairly young and quite happy to go out and socialise ... The other members of the faculty in a social sense tend to be alienated, but not so much in a professional sense (female teacher)

Surprisingly, gender as factor was only referred to twice, once as a stereotype:

like a lot of young female managers, they have got a point to prove and there is an agenda of promotion ... often things are decided on with a career in mind rather than necessarily the 
faculty ... she is quite friendly and quite nice as a person ... [She gets] what she wants with the kids (male teacher)

and once as a significant factor in developing a departmental sub-group:

[We] are all fairly young and quite happy to go out and socialise ... that tends to have gelled us together. [male teacher] does not socialise with us so much - we tend to do girlie things but in terms of the Friday lunch and sitting around chatting, he is there as well (female teacher)

\section{Section Three: Facilitating students' learning}

Middle leaders' views and actions for constructing cohesive departments with staff were echoed in their work with students.

I think the fact that we have this trust in the [students] to time manage and always be on top of their work comes from the way [head of sixth form] is with them ... trusting them, but being there if there is a problem, and being stricter with them to sort something out ... he is the same with staff (female support staff)

In the classroom, too, they signalled a clear vision or purpose, often writing lesson objectives on the board as well as mentioning them orally, showing how one lesson fitted with another. They then engaged inclusively with students to support their work and meet students' learning needs for workrelated knowledge and skills. The teaching and learning was managed effectively to:

make my subject accessible to all students so that they are engaged in history and not turned off by it ... have a variety of teaching styles that apply to different learners. Some get a real kick out of writing reams and reams ... [others] are more into hands on learning, like games, and that sort of thing, discussion work, card activities, where the emphasis is not so much on the writing... but they are still learning history (female subject leader)

However this was no coldly instrumental process but a passionate one. Middle leaders recognised the importance of projecting their and their colleagues' enthusiasm for their subjects and activities. One talked about wanting to have 'dynamic teachers' and perceived the generation of this as her main aim as a subject leader. Several others lauded their own teachers who had been enthusiastic about their subjects. They also recalled those pedagogic practices and modes of relating to students by their former teachers that they now studiously eschewed because of the damaging effect these had had on their own perceptions of subjects. Through their teaching they wanted to ensure:

all students being able to achieve something, and actually encourage students to develop their strengths (female pastoral leader)

as well as to think critically about their work intellectually and morally

I don't ... push any particular religion ... the two Attainment Targets: Learning about religion; and what we can learn from religion ... I try to encourage ... tolerance, so even if they don't like the ideas they don't just right it off as rubbish (male subject leader) 
Embedded in their pedagogy were certain values. One of these was demonstrating care for students' well being through creating high quality resources for them:

kids need to know you care, that you have taken care in making the worksheets ... so they can feel that someone is bothered and therefore they will be bothered (female subject leader)

Another was valuing students as people. 'Kids need to be happy to learn, I think', said one middle leader, while others talked approvingly about those teachers who had valued them when they were students. This was most clearly summed up by one middle leader as:

acknowledging students as individuals and then identifying those areas and encouraging them to develop ... [exam success] is important, and students certainly see that ... but I think it is ... how [students] stretch themselves individually, rather than being focused on [grades] all the time (female subject leader)

They were concerned to help students develop as social beings:

If you succeed at whatever level you are capable of, it will help to prepare you for whatever you go on to ... [and] into your relationship to others ... it is the process of getting [the results] and hopefully the personal and intellectual skills that they develop through that (male subject leader)

\section{Section Four: Middle leaders' reflections on practice}

Middle leaders' reflected on their experiences and biographies to explain the educational values and views that influenced their actions. These experiences were located as often in their lives at home as in their lives as students in school or at university. Less often they referred to events outside these arenas which had been formative in some way. One particular vein of experiences on which they commented was the importance of receiving support at various times from more senior people, usually in their schools, who sponsored their career advancement. This shows the importance of senior staff using their access to power to sponsor more junior staff by offering or encouraging them to take opportunities, or by denying them such support. Another vein was the impact of their social lives on their work or career choices. The world of work was not perceived as an island isolated from the rest of their lives but as part of the fabric. The demands from it had to be balanced against their social and family commitments as they tried to shape their work-related identities as middle leaders. A third vein was the centrality of working with people of all ages and statuses and trying to take cognisance of their needs while leading and managing a subject or pastoral area successfully, exposing the tensions between agency and structure and those between the needs of individuals and the corporation of the school.

\section{Compassionate leaders constructing collaborative learning communities}

This study gives a view of schools and departments as strongly managed centrally by their appointed leaders, reflecting the way in which schools as a whole are managed centrally by and through central government policies in England and Wales, what ever claims government makes for the devolution of control of schools under its scheme of local management (1988). Such constraints seem to reverse Weick's (1976) notion of schools as loosely-coupled organisations. Yet teachers in this study, despite these managerialist constraints, seemed to have establish a form of collaborative 
practice which had many of the hallmarks of developing learning communities, albeit ones in which power was distributed unequally. In part this was because the middle leaders held core values that were communitarian rather than individually competitive and used their access to power, including the authority of their office (Watson, 1969) which arose through the leadership distributed to them by senior staff (Gronn, 2000), to foster staff engagement with decisions and changes in practices to improve teaching and learning. In return they gave staff on-the-job work-related development, when asked for it, which fostered critical reflection on practice.

The construction of a sense of community in these departments was fraught with tensions and contradictions. A key element seems to have been middle leaders' concerns with developing colleagues' senses of self and of agency (Giddens, 1991, 1984) through fostering participation in departmental decision-making and individual pedagogical initiatives within the framework of departmental policy. On the other hand the middle leaders were passionately concerned to meet the needs, as they perceived them, of the students for whom they were responsible. Achieving the latter involved an on-going struggle to improve the quality of teaching and learning despite and because of the macro and institutional policy contexts in which they worked.

Embedded in these contexts were sources of power (Busher, 2001; Bennett, 2001) and asymmetrical power relationships which affected the relationships between middle leaders and their colleagues and shaped the decisions that were taken and the ways in which they could be managed. Thus on the one hand middle leaders tried to create collaborative cultures through a commitment to values of improving teaching and learning and facilitating personal and work-related development among the members of their departments, students and teachers alike. They tried to construct consultative decision-making with their staff colleagues, by using formal and informal channels of negotiation, and to generate social cohesion in their areas through the quality of their interpersonal relationships with colleagues. They were compassionate leaders. Some teachers resisted their efforts, perhaps through not wanting to change their long-established ways of working and interacting with colleagues, but many teachers welcomed their efforts, and students were observed to appreciate their manner of working in lessons.

On the other hand pressures in the institutional contexts as well as middle leaders own educational values led these leaders to require staff to carry out various procedures, the implementation of which they monitored, even if the need for and processes of implementation had been negotiated previously with staff colleagues to gain their consent. Procedures included checking stock in and out of rooms; recording student assessments; and implementing senior staff policies and middle leaders' visions for their departments. Middle leaders justified using such coercive practices to manage their departments by an appeal to core educational values - enhancing student opportunities for learning - and pragmatic concerns with the pressures of external and internal policies on departmental practice.

Although at one level these tensions and asymmetrical relationships made visible the collaborative rather than the collegial nature of the culture in the departments (McGregor, 2000), it also illustrates the balancing act these middle leaders had to perform, weighing principle against the harsh realities of power. They had to be astute politicians to survive successfully, and not merely operationally oriented functionalist managers. What is surprising is that the professional cohesion of the departments does not seem to have been shaken by such actions by the middle leaders. It is argued that in part this was because their colleagues in the departments viewed such activity as legitimate within the hierarchical organisation of a school, and in part because the supportive nature of middle leaders' interpersonal relationships with colleagues helped to sustain it, a conclusion in line with research reported by Blase and Blase (1995). 
The extent to which the collegial cultures associated in theory with learning communities existed in these departments, then, is questionable because some people in the departments had greater access to power than others. However, within the framework of the asymmetrical power relationships that existed, collaborative working processes were sustained, focused around core and apparently widely agreed values for successful teaching and learning and interpersonal relationships. Consequently the departments seemed to have functioned as learning communities, encouraging and supporting their members as they engaged together in tackling the dilemmas they confronted in sustaining successful teaching and learning.

How membership of learning communities in schools is constituted remains problematic. Although students' voices were not recorded in this study, they clearly influenced the processes of lessons and of departmental decision-making, but they could not be said to have been members of the same learning community as the teachers. Teachers and middle leaders were concerned to foster student learning and promote warm interpersonal relationships with them within the hierarchical authority framework of a school. Perhaps the asymmetry of the power relationships between teachers and students was too great to allow a meaningful sense of collaboration to develop. Even the few learning support staff and administrative assistants who were observed in this study were not part of teachers' learning communities. The one who was interviewed, seemed to be at best a partial member. This is similar to findings by Busher and Blease (2000) on laboratory technicians in secondary schools. It raises questions about how far inclusive learning communities can be constructed in schools given the hierarchical distribution of power in such organisations which frame interpersonal relationships in them.

From the foregoing discussion emerge seven indicators by which it might be possible to gauge the extent to which learning communities are developing, at least amongst staff, in a school or department. However these indicators need testing in a much larger scale study before they could be considered to have any predictive value:

- Responsiveness to internal and external policy contexts: middle leaders as mediators and advocates, helping colleagues to come to terms with the contexts in which they work;

- Emergent facilitative leadership: middle leaders helping teachers and other staff to be involved with principled departmental decision about the distribution of financial, physical and intellectual resources to take forward learning and teaching effectively, while taking account of the personal and professional interests of staff in particular policy contexts.

- Evidence of values consensus between department members: a visible and broadly supported coherent vision of the purposes and processes of a department that is constructed by its members and projected by its leader;

- Evidence of open communications systems, using various formal and informal arenas and channels, through which middle leaders listen to and debate with staff colleagues the development of the department in certain directions generally agreed by its members;

- Development of practice through consultation within particular policy contexts: Middle leaders developing changes in practice through discussion with staff on an explicit basis of educational values and educational perspectives in a department;

- Development of social cohesion in a collaborative culture that acknowledges the asymmetrical distribution of power that is embedded in hierarchical organisations while recognising the common humanity and social needs of departmental members.

- Effective reflexive management: Leaders and members improving practice collaboratively through monitoring and evaluating practice in the light of an explicit value base for decision making. 
In this study middle leaders seem to have gone some way to constructing learning communities with their staff colleagues, within the constraints of hierarchically organised education institutions. But the cultures that emerged were collaborative rather than genuinely collegial, and were predicated on shared and communitarian social and educational values, rather than on marketoriented individualistic and competitive ones. Although these developing learning communities did not include students, many of their members seemed committed to facilitating the participation and engagement of all their students in successful learning and in decision-making about how they engaged more or less successfully with the work (curriculum) they had to undertake in order to promote their personal and work-related development. 


\section{References}

Aubrey, C. David, T. Godfrey, R and Thompson, L. (2000) Early childhood educational research: Issues in methodology and ethics (London, RoutledgeFalmer)

Bennett, N (2001) Power, structure and culture: An organisational view of school effectiveness and school improvement in Bennett, $\mathrm{N}$ and Harris, A (eds) School effectiveness and school improvement: searching for the elusive partnership (London, Continuum)

Blase, J. and Anderson, G. L (1995), The micro-politics of educational leadership: From control to empowerment (London, Cassell)

Blase, J and Blase, J (1994) Empowering teachers: What successful Principals do. (Thousand Oaks, Ca, Corwin)

Blase, J and Blase, J (1995) The micro-political orientation of facilitative school principals and its effects on teachers' sense of empowerment. Paper given at the (American Educational Research Association (AERA) Conference, San Francisco, April 1995)

Bottery, M. (2003) The leadership of learning communities in a culture of unhappiness Paper given to the ESRC Seminar Series Challenging the orthodoxy of school leadership: Towards a new theoretical perspective, (National College for School Leadership, UK, June 2003)

Bourdieu, P and Passeron, J-C (1977) Reproduction in education: Society and culture London: Sage Bradley, C and Roaf, C (1995) Meeting special educational needs in the secondary school: a team approach Support for Learning 10, 2, pp.93-99

Busher, H (2001) The micro-politics of change, improvement and effectiveness in schools, in Bennett, N and Harris, A (eds) School effectiveness and school improvement: searching for the elusive partnership (London, Continuum)

Busher, H and Blease, D (2000) Growing Collegial cultures in subject departments in secondary schools: working with Science staff School Leadership and Management 20,1, pp.99-112 Busher, H and Harris, A (1999) Leadership of School Subject Areas: tensions and dimensions of managing in the middle, School Leadership and Management 19, 3, pp. 305-317.

Busher, H and Saran, R (1992) Teachers' Conditions of Employment: a study in the politics of school management, (London, Bedford Way Series, Institute of Education, University of London / Kogan Page)

Busher, H and Saran, R (1995) Managing with support staff in H. Busher and R. Saran (eds) Managing teachers as professionals in schools. (London, Kogan Page)

Busher, H and Barker, B (2003) The crux of leadership: Shaping school culture by contesting the policy contexts and practices of teaching and learning Educational Management and Administration 31, 1, pp.51-65

Clark, D. (1996) Schools as learning communities: Transforming education (London, Cassell)

Cooper, P. Drummond, M. Hart, S. Lovey, J. and McLaughlin, C. (2000) Positive alternatives to exclusion, (London, RoutledgeFalmer)

Cooper, P and McIntyre, D. (1996) Effective teaching and learning: Teachers' and students' perspectives, (Milton Keynes, Open University Press)

Dearing Commission (1993) The National Curriculum and its assessment: Final Report (London, School Curriculum and Assessment Council)

Fullan, M (2003) The moral imperative of school leadership (Thousand Oaks, Ca, Corwin Press)

Giddens, A (1979) Central problems in social theory (Cambridge, Polity Press)

Giddens, A. (1984) Constitution of society (Cambridge, Polity Press)

Giddens, A. (1991) Modernity and self-identity: Self and society in the late modern age

(Cambridge, Polity Press)

Gray, L. (1991) Marketing Education (Milton Keynes, Open University Press) 
Greenfield, T. B and Ribbins, P. (1993) Greenfield on Educational Administration (London, Routledge)

Gronn, P (2000) Distributed properties: A new architecture for leadership Educational Management and Administration 28, 3, pp.317-338

Gronn, P (2003) Leadership: Who needs it? Paper given to the ESRC Seminar Series Challenging the orthodoxy of school leadership: Towards a new theoretical perspective, (University of Birmingham, UK, February 2003)

Gunter, H., McGregor, D. and Gunter, B. (2001) 'Teachers as leaders: A case study', Management in Education, 15,1, pp.26-28.

Hargreaves, A (1994) Changing teachers, changing times: Teachers' work and culture in the postmodern age (London, Cassell)

Hodgkinson, C (1999) The triumph of the will: An exploration of certain fundamental problematics in administrative philosophy P. T. Begley, and P. E. Leonard, (eds) (1999) The Values of

Educational Administration (London, Falmer Press)

Hopkins, D (2001) Improving the Quality of Education for All (London, David Fulton)

Howard, S. and Gill, J. (2000) 'The pebble in the pond: Children's constructions of power, politics and democratic citizenship', Cambridge Journal of Education, Vol.30, No.3, pp.355-378.

Hoyle, E (1981) Management and the school, Block 3, E323 Management Processes in Schools (Milton Keynes, Open University Press)

Linstead, S. (1993) Deconstruction of the study of organisations in J. Hassard and M. Parker (eds) (1993) Postmodernism and organisations (London, Sage)

Louis, K. Marks, H. and Kruse, S. (1996) Teachers' professional community in restructuring schools. American Educational Research Journal 33

McGregor, J (2000) The challenge of collaboration: What encourages joint working between teachers? Paper given at the Sixth quadrennial BEMAS research conference, (Robinson College, Cambridge, UK, 2000)

Marsh, M (1997) In conversation with Janet Ouston in, P. Ribbins (ed) (1997) Leaders and leadership in the school, college and university (London, Cassell)

Measor, L. and Sikes, P. (1992) Visiting lives: Ethics and methodology in life history in I. Goodson (ed)(1992) Studying teachers' lives (London, Routledge)

Murphy, J. (1992). The landscape of leadership preparation. (Newbury Park, CA, Crowin Press) Nias, J (1999) Primary teaching as a culture of care, in Prosser J (ed) School Culture (London, Paul Chapman)

Ribbins, P (1997) Leaders and leadership in the school, college and university (London, Cassell) Ribbins, P (1999) Foreword in P. T. Begley, and P. E. Leonard, (eds) (1999) The Values of Educational Administration (London, Falmer Press)

Rudduck, J. Wallace, G. and Chaplain, R. (1996) School improvement: What can pupils tell us? (London, David Fulton)

Rudduck,J and Flutter, J. (2000) Pupils Participation and Pupils Perspective: 'carving a new order of experience'. Cambridge Journal of Education. 30, 1, pp.75-89.

Sammons, P. Thomas, S and Mortimore, P (1997) Forging Links: Effective Schools and Effective Departments. (London, Paul Chapman)

Schon, D (1987) Educating the Reflective Practitioner: Towards a new design for teaching and learning in the professions (San Francisco Ca, Jossey Bass)

Senge, P (1990) The fifth discipline (New York, Doubleday)

Sergiovanni, T. (1994) Building Community in schools. (San Francisco, Ca, Jossey-Bass)

Siskin, L. (1994) Realms of knowledge: Academic departments in secondary schools, (London, Falmer Press)

Stoll, L and Fink, D (1996) Changing our schools: Linking school effectiveness and school improvement (Buckingham, Open University Press) 
Smylie, M. (1994) Redesigning teachers work: Connections to the classroom, in L. DarlingHammond (ed) Review of research in education (Washington DC, American Educational Research Association)

Smyth, J. Dow, A. Hattam, R. Reid, A. and Shacklock, G. (2000) Teachers' work in a globalising economy (London, Falmer Press)

Tannenbaum, R and Schmidt, W (1973) How to choose a leadership pattern Harvard Business Review .51, 3, pp.162-180

Thomas, D. (1995) Treasonable or trustworthy text: Reflections on teacher narrative studies in D.

Thomas (ed) (1995) Teachers' stories (Buckingham, Open University Press)

Van der Westhuizen, P. (1996) Resistance to change in educational organisations paper given at the Fifth Quadrennial Research Conference of the British Educational Management and

Administration Society, (Robinson College, Cambridge University, UK)

Wallace, R. Engel, D. and Mooney, J (1997) The Learning School: A guide to Vision based leadership (Thousand Oaks, Ca., Corwin Press)

Watson, L (1969) Office and expertise in the secondary school Educational Research, 11, 2, pp.104-112

Weick, K.(1976) Educational organisations as loosely coupled systems, Administrative Science Quarterly, 21, 1, pp.1-19

West-Burnham, J. (1992) Managing quality in schools: A TQM approach (Harlow, Longman) Wragg, E.C., Haynes, G.S., Wragg, C.M. and Chamberlin, R.P. (2000) Failing Teachers? (London, Routledge) 